\title{
Two Democratic Traditions in The Election of Head The Village in Neglasari, Tasikmalaya
}

\author{
IYEP SAEFULRAHMAN \\ Faculty of Social and Political Science, Padjadjaran University \\ email: sef73rahman@gmail.com
}

\begin{abstract}
This study aims to analyze the working of two democratic traditions in the election of head of Neglasari Village in 2015. This aim based on the condition of Neglasari as a unity of law society that has its own tradition in implementing democracy. However, the state determines that liberal democratic tradition is the main traditions that applied in head of village election. The research uses qualitative research and case study as its research strategy. Data collecting is done by interview, observation and documentation. The working of both democratic traditions turns out to provide a positive contribution, to the village democracy to be more qualified because both traditions are supporting each other.
\end{abstract}

Keywords: tradition of democracy, chief of village election, local leadership (sesepuh)

\section{Introduction}

A village is a unity of law society that exists long before the existence of a state. Although the government of Dutch East Indies found it in 1817 (Kartohadikoesoemo, 1984), it existence was long before at least during the era of the Singhasari Kingdom established in 1222-1292 and it was known as desa perdikan (Maschab, 2013). It means that village has a long history and continues in a dynamic along with the development of the kingdom that copes it until its current form.

The condition, however, did not mean that the power and existence of a village is higher than that of the state. The substantial power of the state is the main causing factor of the condition. With its power, a state has the authority to set the direction of development, form and pattern of the governance and the development of a village including in the election of its head of village. In other words, a village depends on more to the good will and political will of the state.

At present, the regulation on village is set by Act No. 6, 2014 on village. The act states that head of village is directly elected by its people and the election is conducted simultaneously. The regulation of the simultaneous election is a new thing in the election of head of village for all unity of law societies in Indonesia including Neglasari Village in Salawu Sub-district, Tasikmalaya Regency, West Java. The most important thing in this election of head of village, however, is not its simultaneous nature but the regulation in the act to maintain the implementation of the mechanism of direct election of head of village by its people. The mechanism is part of liberal democratic tradition to elect the leader.

The problem is that although Neglasari Village is not a unity of customary law society, it has its own tradition in the election of the head of village. The tradition came from the custom of Kampung Naga society who still exist and effectively to be the guidance for people of Neglasari in their social life, governing and democracy. Kampung Naga itself is one of kampongs in the area of Neglasari Village. According to Ningrum (2012), for Naga people, custom has a unifying force (centripetal) that could weaken the external strengths that have split force (centrifugal). This Naga custom is summarized in four traditions: will, mandates, prohibitions and consequences.

Although it is different from New Order Era, the tradition is still effective in electing

Received: May 24, 2016, Revision: November 15, 2016, Accepted: December 19, 2016

Print ISSN: 0215-8175; Online ISSN: 2303-2499. Copyright@2016. Published by Pusat Penerbitan Universitas (P2U) LPPM Unisba Accredited by DIKTI. SK Kemendikbud, No.040/P/2014, valid 18-02-2014 until 18-02-2019 
and assigning the head of village including in 2015 election. Therefore, the democratic tradition worked in the election of head of Neglasari village is not only liberal tradition set by the government with its direct election but also local tradition conducted through babadamian of village elders (sesepuh).

The interesting part is that the work of the two democratic traditions in the election of head of village creates no impact despite the value of the constituent of both traditions that in the confrontation. Boeke (1983) gave an illustration in the economic life of villagers that when two values exist in a society (external and internal values in the society) those values will confront each other. The external value will always try to dominate and in the end, replace the internal value.

The research will not discuss on things causing the existence of two democracies in Neglasari; instead it focus on the election process of head of village in Neglasari in 2015 and the work of two democratic traditions in the election and the leadership of village sesepuh (elders) that gave impact in establishing the direction of support of the people to candidates set through local democracy.

\section{Framework}

The village is a unity of residency law of a society with the power to conduct its own government (Boeke,1971; Kartohadikoesoemo, 1984). One of the manifestations of its power is in democracy, especially in the election of its leader (head of village). Democracy for villagers is one of village traditions. It means that the existence of democracy inherent in the life of the villagers. Even for Moh. Hatta (2009), village democracy is the real democracy. Its existence is not merely a tradition but it grows, develops and lives as a custom. The basic is in the consentience act. The common act, according to Sobarna (2002), is part of democracy in the perspective of gathering (silaturahmi) that consists of (a) cooperative relation above competitive relation; (b) polite criticism; (c) positive thinking; (d) think win-win; (e) fair; (f) take and give; and (g) having social solidarity.

According to Kartohadikoesoemo (1984), village democracy is a construction of democracy based on the principle of divinity and conducted based on "manunggaling kawulo-gusti (direct and personal relationship between human and their God)" philosophy. Democracy based on divinity can be defined as "a view of life that gives full value and opportunity to each individual in their movement to unite in a whole instead of separating themselves from their origin." It means that our pure democracy is to look for unifying matters instead of separating.

Further, Kartohadikoesoemo (1984) explained that system used in democracy is based on divinity, which is musyawarah dan mufakat (deliberation and consensus), in form of village meeting. It means that all decision made by the meeting is based on acclamation (consensus) after a deliberation. A village meeting is the culmination (culminatepunt) of the implementation level of divinitybased democracy. It means that divinity in democracy practice in the village is placed on top of the people through village meeting and not on the authority of single leader. Therefore, through the deliberation, the agreement reached is based on shared consideration. In other words, the deliberation system is aimed to achieve shared victory against oneself instead of unilateral victory.

Construction of the original village democracy is different to the form of western democracy (liberal democracy) or representative democracy. In liberal tradition, appreciation to individual freedom (individualism) is the main thing in democracy (Moh. Hatta, 2009). Therefore, liberal democracy becomes the aggregation of individual preferences (Grugel, 2002). Concrete example of the appreciation to individual right can be seen in the parliamentary election and decision making that use direct voting model (Nederveen, 2001). Voting is considered as the highest success in democracy as the manifestation of people responsibility (Veil, 2008).

Based on the above explanation, liberal democracy indicates spirit or individual rights that placed above the "common interest." The voting as a chosen method led to a decision which not based on acclamation or agreement in acclamation but rather to the competition to get the most votes. Therefore, it hard to discover who wins and who loses. The difference between both democracies can be seen on the following Table 1.

There are two factors to be considered in village democracy: internal and external factors (Suwarno, 2000). Internal factors consist of demos (people) and kratos (institution). The demos of a village consist of people who occupy a settlement due to blood relation and/or the same residence area. They relate to each other and form a community. 
Table 1

The Difference between Two Democratic Traditions

\begin{tabular}{|l|l|l|l|}
\hline No & Item & Local & Liberal \\
\hline 1 & Source & Local tradition (village) & Liberal tradition (western) \\
\hline 2 & Spirit & Togetherness & Individual freedom \\
\hline 3 & Principle & Shared agreement & Majority victory \\
\hline 4 & Organization & $\begin{array}{l}\text { Village meeting atau rembug } \\
\text { Desa, Forum of sesepuh (elder) }\end{array}$ & $\begin{array}{l}\text { Political party, parliament, general } \\
\text { election }\end{array}$ \\
\hline 5 & Method & Deliberation & Voting (one man one vote) \\
\hline 6 & Result & Consensus & The most votes \\
\hline
\end{tabular}

On the other hand, Kratos developed is gotong royong (mutual cooperation) that incarnate in form of primus inter pares. In this condition, residents participate in decision making; the final decision, however, is in the hand of the elders who are considered as primus. The decision made will bind all residents and any violation against it will cause social sanction. Meanwhile, the external factors are top government and social, economic and cultural factors.

Based on the finding, it can be stated that in village democracy, the leader has an important position. Through his/her leadership, he/she could build the direction of village democracy, especially, in decision making due to the trust put by his/her people in him/her. For a village that put tradition as part of the cultural factor, its existence should be considered since it can give contribution to the direction of democratic culture to be built. The role of the state cannot be ruled out. In fact, with its authority, the state can be the main determinant in building the direction and tradition of democracy to be applied by the village. The provision to apply liberal tradition in the election of head of village is one of the authorities owned by the state. In the context of head of village election, regardless the positive or negative impact, economic motives and self- prestige when becoming a village leader could contribute to the democracy of the village. With these motives, villagers will have desire to directly participate in democracy in their village, either to elect or to be elected.

The authorities owned by the state in determining the direction and tradition of democracy, in the end, will allow the creation of three patterns in village democracy. The first pattern is based on local tradition; in the second pattern the basis has shifted into liberal tradition, and the last pattern combines local tradition and liberal tradition. In this third pattern, the combination of local and liberal traditions create three sub-pattern based on whether both traditions are dominant or not when it applied in village democracy. Simply, the framework is described in the following figure.

\section{Research Method}

The research used the qualitative approach with the post-positivist paradigm. It is based on the aim of the research to describe and analyze the work of two democratic traditions in the election of head of Neglasari village. Local tradition in democracy in Neglasari that survives since it comes from Islamic teachings and Naga culture was the consideration to conduct qualitative research. Therefore, due to this characteristic, according to Nasution (2003), Sugiono (2005), dan Irawan (2007), it is appropriate to apply qualitative research since the research focus was directed more to the disclosure of the meaning behind facts to be seen. As well as the linkage between two democratic traditions that work in the election of the head of village that allow giving other meanings to the visible facts obtained by the researcher.

The strategy chosen to answer the research purpose is a case study since it gives space in depth research problem. The aim of this case study is to learn more about the work of two democratic traditions in the election of head of Neglasari village in 2015. The detail of revealing specific things will be obtained through case study strategy, especially those related to the process of head of village election and the influence of local leadership in building the direction of the election of head of Neglasari village.

Data collection techniques used are unstructured interview, documentation and, observation by living in the village. The Interview was conducted mainly with the Committee of Head of Village Election 2015 
and was related to the regulation and election process as well as the enforcement of regulation in the election of head of Neglasari village. In addition, interview was conducted with the village elders (sesepuh) related to the existing tradition that still works today in the 2015 election. The Research was conducted in the head of village election for period of 2015-2021, which was held on October 2014 - March 2015.

\section{Two Democratic Traditions in the Election of Head of Neglasari Village of $\mathbf{2 0 1 5}$}

Regulation in the election of head of Neglasari village consists of UU (Act) No. 6, 2014 on Village, PP (Government Regulation) No. 43, 2014 on Implementing Regulation related to UU No. 6, 2014 on Village, Permendagri (Regulation of the Minister of Home Affairs) No. 112, 2014 on the Election of Head of Village, and Perbup (Regents Regulation) No. 4, 2014 on the Termination of Head of Village in Tasikmalaya Regency. Based on those regulations, it was found that stages in the present simultaneous election of the head of village were preparation, candidacy, voting, and appointment (in Act No. 6, 2014 there are only three election stages: candidacy, voting and appointment).

The government of Tasikmalaya Regency, formally, just set activities schedule for each stage in the beginning of January 2015. With simultaneous election, it means that all villages that have their head of village election will have the same schedule. In Neglasari, however, the formation of the Committee (later known as Committee 11) was conducted in October 3, 2014 through village meeting using consensus method in which the implementation was represented by figures (leaders) from each RT (neighborhood association), community institutions (LPMD, PKK, MUI, Karang Taruna), village government including the head of RW (neighborhood unit - comprising several RTs) and RT, and Bamusdes (village deliberative agency) as the responsible party.

The result of the consensus set that the formed Committee should consist of the village, community institution, public figures, and the existence representation for each kapunuhan (hamlet) in Neglasari Village. Government regulation issued recently in form of Perbup (regents regulation) No. 4, 2014 which include the determination of activities schedule in the enforcement of head of village election consisting of 13 (thirteen) activities. The activities are started with socialization, data collection and determination of voters, selection, filtering, and determination of candidates, campaign, voting, counting, and the appointment of elected head of village candidates.

In addition to the formal activities set by the government, there were informal activities conducted in the election of head of Neglasari village, which was part of the tradition owned by Neglasari in democracy. Although it has gone through many changes, the tradition still works effectively in village democracy, especially in the election of head of village. The tradition is babadamian. Babadamian is a way to make a decision through consensus among sesepuh (village elders) to reach shared agreement. Babadamian is the real form of the existence of local democratic tradition in the election of head of village. The state, itself, through Act No. 6, 2014 on Village and legislations as the procedure, has set liberal democratic strategy as the tradition that should be applied in the election of head of village through direct election method with one man one vote and the result set based on the most votes.

In the empirical level, local tradition precedes the liberal tradition. For example, the mechanism of the formation of committee used method of villagers' consensus. The decision was made based on the agreement and consideration on common interest. Babadamian itself, during the election of head of village, does not work in the frame of electing head of village; instead, it only determines the appropriate candidates based on the appraisal of sesepuh. Final decision for the elected candidate would be in the hand of villagers through direct voting. It means that the elected head of village was still the one who gains the most votes in direct election by the villagers and not based on the determination of babadamian result. In other words, final decision of the elected candidate will be based on liberal democratic tradition. The work of the two democratic traditions can be seen in Table 2.

Based on the above table, it can be seen that it was in the candidacy stage where the two traditions worked together. Local tradition worked first by conducting selection on all people eligible to be nominated as the head of village. This Babadamian was not conducted informal way as previously during the New Order era, but informally among the village 
MiMBAR, Vol. 32, No. $2^{\text {nd }}($ December, 2016), pp.311-318

Table 2

Matrix on the Work of Two Traditions in the Election of Head of Neglasari Village

\begin{tabular}{|l|l|l|}
\hline \multirow{2}{*}{ Election Stages } & Democratic Tradition \\
\cline { 2 - 3 } & Local & Liberal \\
\hline Preparation & $\begin{array}{l}\text { The formation of committee through } \\
\text { village consensus }\end{array}$ & X \\
\hline Candidacy & Babadamian of the sesepuh & Selection by Committee 11 \\
\hline Voting & $\mathrm{X}$ & Directly by the villagers \\
\hline $\begin{array}{l}\text { Appointment of } \\
\text { Elected Candidate }\end{array}$ & $\mathrm{X}$ & Based on the most votes and equal \\
\hline
\end{tabular}

Source: Research Result, 2015

sesepuh. In addition, the implementation was not in a consensus forum as previously conducted since the existence of the forum has gone during the New Order era.

Based on the result of babadamian, actually there were 2 (two) candidates received "approval" or who were met the comfortability aspect from the sesepuh. Both candidates were Mr. Sobirin, candidate number 3 (three), who is the incumbent party and Mr. Henhen from Kampung Naga, candidate number 4 (four). The comfortability of the sesepuh was based on the capability aspect of the candidates (morals and leadership) where in its tradition the candidate of leader should have characters of cageur (physically and mentally healthy), bageur (kind-hearted), bener (honest), pinter (smart), and singer (diligent).

Approval received from the sesepuh through babadamian by candidates was the tradition that effectively works in the election of head of Neglasari village. With this approval, the candidates would have a big opportunity to be elected as the head of the village by gaining the most votes. It means that comfortability from the sesepuh is a determinant factor for the success of the candidate to gain acceptability from the villagers. The reason is that sesepuh have the ability to directly and indirectly influence people in determining their choice (leadership).

Whereas for two other candidates, Mr. Yaya (candidate No.1) and Mr. Jajang (candidate No. 2) did not meet the comfortability aspect of village sesepuh. However, since babadamian and sesepuh has no authority to forbid their candidacy, both candidates were still registered. In addition, the state gives a guarantee of freedom for each individual to use their right including the right to be elected as the head of village as long as he/she is qualify based on the requirements set by the state (liberal tradition). Based on the information, the policy on village funds to be given by government gave certain attraction for both candidates to proceed in the election. Whereas, if refer to the existing tradition, if the candidates do not meet the comfortability aspect from sesepuh, the opportunity to gain support from the villagers (acceptability) is low.

The list of final voters in the election of head of village of 2015 in Neglasari was 4,338 people. The highest turnout was in Kapunuhan Naga as much as 1,631 people and the least was Cikeusik as much as 608 people. During the voting, voters who used their vote was 3,269 people or about $75.36 \%$ (lesser than presidential election of 2014 where the turnout was $74.80 \%$ ). Of the voters who used their right, about 1,653 voters or $50.57 \%$ gave their vote to candidate No. 4 , Mr Sobirin (see Table 3).

The victory of Mr. Sobirin in the election of head of village 2015 by gaining the most votes is in accordance with the joint decision of sesepuh. As previously explained, prior to the liberal tradition worked through direct voting by eligible villagers, local democratic tradition through babadamian (deliberating) worked first. During the selection, filtering, and determination of candidates, it was clear which would be more acceptable to the villagers. Although there were two candidates who met the comfortability aspect of village sesepuh, but Mr. Sabirin was the only candidate who received approval from sesepuh evenly. As for Mr. Henhen, although he met the comfortability aspect, the approval was only from sesepuh and some of pinisepuh of Kampung Naga since he is the brother of the traditional leader (kuncen) of Kampung 
Table 3

Vote for Candidates of Head of Village per Kapunuhan in the Election of Head of Neglasari Village in 2015

\begin{tabular}{lcllll}
\hline & KAPU-NUHAN & \multicolumn{4}{c}{ NUMBER OF CANDIDATES } \\
\cline { 3 - 5 } & DESCRPTION & $\mathbf{1}$ & $\mathbf{2}$ & $\mathbf{3}$ & $\mathbf{4}$ \\
\hline Cikeusik & Total Votes & 50 & 83 & $\mathbf{2 6 3}$ & 53 \\
Total Voters Who Came and Valid & 449 & 449 & 449 & 449 & \\
Percentage & $11,14 \%$ & $18,49 \%$ & $58,57 \%$ & $11,80 \%$ \\
Naga & Total Votes & 48 & 183 & 424 & $\mathbf{6 3 5}$ \\
Total Voters Who Came and Valid & 1.290 & 1.290 & 1.290 & 1.290 \\
Percentage & $3,72 \%$ & $14,19 \%$ & $32,87 \%$ & $49,22 \%$ \\
Sukaratu & Total Votes & 31 & 231 & $\mathbf{2 9 5}$ & 73 \\
Total Voters Who Came and Valid & 639 & 639 & 639 & 639 \\
Percentage & $4,85 \%$ & $36,15 \%$ & $46,18 \%$ & $11,42 \%$ \\
Tanjaknangsi & Total Votes & 11 & 196 & $\mathbf{6 7 1}$ \\
Total Voters Who Came and Valid & 891 & 891 & 891 & 891 \\
Percentage & $1,23 \%$ & $21,99 \%$ & $75,31 \%$ & $1,46 \%$ \\
NEGLASARI & Total Votes & 140 & 693 & $\mathbf{1 . 6 5 3}$ & 774 \\
Total Voters Who Came and Valid & 3.269 & 3.269 & 3.269 & 3.269 \\
Percentage & $4,28 \%$ & $21,20 \%$ & $50,57 \%$ & 23,68 \\
\hline
\end{tabular}

Source: Committee of the Election of Head of Neglasari Village 2015

Naga. Regarding Mr. Sabirin, although he is not native of Kampung Naga, he met the comfortability aspect from some pinisepuh of Kampung Naga. In addition, he has better capability than Mr. Henhen as well as he has close relationship with Kampung Naga based on his descendant background since his grandfather was one of pinisepuh of Naga.

The prevalence of comfortability from sesepuh for Mr. Sobirin was in line with the prevalence of the votes he gained in each kapunuhan. Although he lost from Mr. Henhen in Kapunuhan Naga, the vote was not too different than Mr. Henhen. Kapunuhan Naga was the basis of support of Mr. Henhen proven with 635 votes he gained in the area or about $49.22 \%$; whereas, Mr. Sobirin gained 424 votes or $32.87 \%$. Whilst, in 3 (three) other kapunuhans, the difference in votes gained by both candidates was relatively big. In Kapunuhan Cikeusik, Mr. Sobirin surpassed Mr. Henhen with comparison of 263:53 or $58 \%$ to $11.80 \%$. In Sukaratu, the difference was significant with 295 votes (46.18\%) for Mr. Sobirin and 73 votes $(11.42 \%)$ for $M r$. Henhen. Whereas, in Tanjaknangsi it was very significant since the kapunuhan was the base of support of Mr. Sobirin. Therefore, it was not surprising if his votes reached 891 votes
(75.31\%) compare to 13 votes $(1.46 \%)$ for Mr. Henhen.

Meanwhile, two other candidates, Mr. Yaya (candidate No. 1) and Mr. Jajang (candidate No. 2), since they did not meet the comfortability aspect, so as predicted, they gained relatively small votes, especially for candidate No. 1 who got 140 votes (4.28\%). Tradition has become factor that causing the small vote. The candidate is not native of Neglasari or a sanaga. Mr. Jajang, on the other hand, got more votes of 693 votes (21.20\%). Besides he is part of sanaga, the "giving" strategy applied by the candidate was fairly effective to attract support from some villagers. However, his vote was low compared the vote got by Mr. Henhen.

The victory of Mr. Sobirin in the voting as part of liberal tradition was an indication that villagers still put high trust in the leadership of village sesepuh. It means that, in the election of head of village in Neglasari, the election result based on liberal democratic tradition was in line with the election result of the sesepuh based on local democratic tradition. This conclusion was drawn since Mr. Sobirin, through babadamian, was the first choice of the sesepuh to lead Neglasari. 
In the election of head of village, the work of two traditions was not mutually exclusive or in a confrontation. Liberal tradition as a tradition set by the state and formally applied in the election of head of village cannot replace local tradition as a whole. The existence of liberal tradition is only shifted the position of local tradition as the first base in the democracy of Neglasari village. Currently, local democratic tradition works only informally before liberal tradition is applied. It is the cause why both traditions could work harmoniously and complete each other. Although both traditions work in the same arena, which is in the election of head of village, the application time was different for both traditions. Local tradition is informally worked before the liberal tradition applied by the state in formal way by the committee. In a simple way, the working process of both traditions can be seen in the following figure.

The occurrence of the condition cannot be separated from the strong local leadership within village sesepuh that able to play the role of local democratic tradition in the middle of demand to apply liberal democratic tradition. When applying local democratic tradition, village sesepuh did not confront it directly with liberal democratic tradition since the position is formally low before the state. In this case, local democratic tradition worked to fill and complete the weaknesses of liberal tradition that focuses only on procedural aspect. Whereas, the substantial aspect such as, competency that required for a candidate of liberal tradition, received less attention; therefore, sometimes a candidate who get the most vote has no capability to be a leader. On the contrary, the application of liberal tradition gives big contribution in the development of village democracy in Neglasari due to the competition and participation, which are the important part of democracy in the contemporary perspective.

\section{Conclusions}

In the election of Head of Neglasari Village, there were two traditions that worked harmoniously, local tradition through babadamian and liberal tradition through direct voting by the villagers. Local tradition worked formally and it was conducted before liberal tradition that worked formally. The result of babadamian of the sesepuh was apparently still believed by the villagers; therefore, during the voting, the candidate who was elected by the sesepuh, received the most votes. The leadership of village sesepuh was the determinant factor. The work of two traditions gave a positive contribution to village democracy, especially in the election of head of village since both were able to fill and complete each other's weaknesses. Therefore, harmonization in democracy was marked with the work of local and liberal democratic together, especially in the election of the head of village and was able to create more qualified village democracy.

With the resulted quality of democracy, the state (government) should give authority to local tradition to work in developing village democracy. Therefore, the state no longer unilaterally set liberal tradition as the only tradition that should be applied by the village in the election of the head of village. Concrete step for the improvement is by referring to UU No. 6, 2014 on Village, especially to articles that regulate the election of the head of village.

\section{References}

Boeke, J.H. (1971). Batas-batas Dari Masyarakat Pedesaan Indonesia. (terjemahan LIPI kerjasama dengan KITLV) Jakarta: Bhratara

Boeke, J.H. (1983). Prakapitalisme Di Asia. Jakarta: Sinar Harapan

Grugel, Jean. (2002). Democratization: A Critical Introduction. New York: Palgrave. Hatta, Moh. 2009. Demokrasi Kita. Pikiran-Pikiran Tentang Demokrasi dan Kedaulatan Rakyat. Bandung: Sega Arsy

Irawan, Prasetya. (2006). Penelitian Kualitatif dan Kuantitatif Untuk IImu-ilmu Sosial. Jakarta: Departemen Ilmu Administrasi Universitas Indonesia

Kartohadikoesoemo, Soetardjo. (1984). Desa. Jakarta: PN Balai Pustaka

Maschab, Mashuri. (2013). Politik Pemerintahan Desa di Indonesia. Jogyakarta: PolGov

Nasution, S. (1988). Metode Penelitian Naturalistik Kualitatif. Bandung: Tarsito

Nederveen, Pieterse J. (2001). Participatory Democratization Reconseived. Futures 33 p. 407-422.

Ningrum, Epon. Dinamika Masyarakat Tradisional Kampung Naga di Kabupaten Tasikmalaya. MIMBAR (Jurnal Sosial dan Pembangunan), [S.I.], p. 47-54, june 2012. ISSN 2303-2499. Tersedia pada: <http://ejournal.unisba.ac.id/ index. php/mimbar/article/view/338>. Tanggal Akses: 26 june 2016,

Pemerintah Daerah Kabupaten Tasikmalaya. 2014.

Peraturan Bupati No.4 Tahun 2014 tentang 
Pedoman Pencalonan, Pemilihan, Pengangkatan, Pelantikan dan Pemberhentian Kepala Desa di Kabupaten Tasikmalaya, Republik Indonesia. 2014. Undang-undang No. 6 Tahun 2014 tentang Desa.

Sobarna, Ayi. Nilai-Nilai Demokrasi Sebagai Dasar Partisifatif. MIMBAR (Jurnal Sosial dan Pembangunan), [S.I.], p. 31- 53, mar. 2002. ISSN 2303-2499. Tersedia pada: <http://ejournal.unisba.ac.id/ index.php/ mimbar/article/view/62>. Tanggal Akses:
26 june 2016

Sugiono. (2005). Memahami Penel itian Kualitatif. Bandung: Alfabeta

Suwarno, PJ. (2000). Demokrasi Desa di Indonesia Melacak Akar dan Sejarahnya dalam Dadang Juliantara (penyunting). 2000. Arus Bawah Demokrasi. Yogyakarta: Pustaka Pelajar.

Veil, Shari R. (2008). Civic Responsibility and Risk Democracy. Public Relation Review p. 387-391. 